\title{
DUKUNGAN TEMAN SEBAYA DALAM MENINGKATKAN MOTIVASI BELAJAR
}

\author{
Nur Cahaya Nasution \\ Psikologi Pendidikan Islam, UIN Sunan Kalijaga Yogyakarta \\ Email: nurcahaya1711@gmail.com
}

\begin{abstract}
Adolescence is known as a period of self-identification. Along with its development, the desire toassociate and get to know other people began to appear more intensively. In this phase of the search for self-identity, many teenagers experience a self-identity crisis due to failure to recognizetheir identity. For the sake of searching for self-identity, teenagers are very sensitive torelationships especially with peers. Peers are people who have the same age level, the same behavior or behavior and tend to have the same habits. Of course, the very urgent thing expected from peers is that they can help each other and influence each other and exert themselves to have a strong motivation in learning. One of the factors that can increase learning motivation is peer-group interaction, Islam considers that a barometer of peers is a human awareness to choose and have good friends who can strengthen their piety towards their religion, bring benefits and benefits and guide them towards the positive that is loving and berijtihad in studying. In this discussion, the peers in question are students who are educated at the junior secondary level.
\end{abstract}

[Masa remaja dikenal dengan masa pencarian identitas diri. Seiring dengan perkembangannya, maka mulai muncul keinginan untuk bergaul dan mengenal orang lain lebih intensif. Banyak pula pada fase pencarian identitas diri ini, para remaja mengalami krisis identitas diri dikarenakan kegagalan mengenali jati dirinya.Demi pencarian identitas diri, maka remaja sangat sensitif terhadap pergaulan apalagi dengan teman sebaya. Teman sebaya adalah manusia yang memiliki tingkat usia yang sama, perbuatan atau tingkah laku yang sama dan cenderung memiliki kebiasaan yang sama. Tentunya hal yang sangat urgen diharapkan dari teman sebaya adalah mereka dapat saling membantu dan saling mempengaruhi serta mendahsyatkan diri masing-masing untuk memiliki motivasi yang kuat dalam belajar. Salah satu faktor yang dapat meningkatkan motivasi belajar adalah pergaulan teman sebaya (peergroup), Islam memandang bahwa barometer terhadap teman sebaya merupakan suatu kesadaran manusia untuk memilih dan memiliki teman yang baik yang dapat memperkuat keistiqamahannya terhadap agamanya, membawa maslahat dan manfaat serta menuntun ia kearah yang positif yaitu mencintai dan berijtihad dalam menuntut ilmu. Dalam pembahasan ini, teman sebaya yang dimaksud adalah para siswa yang mengenyam pendidikan di tingkat SLTP].

Keywords: Peer Group, Learning Motivation.

\section{PENDAHULUAN}

Motivasi belajar dapat dipengaruhi oleh beberapa faktor, diantaranya faktor internal dan faktor eksternal yang tujuannya adalah untuk melakukan suatu tadarruj(perubahan) menuju masa depan yang cerah gemilang yang dibekali dengan tumpukan ilmu pengetahuan. 
Adapun salah satu faktor yang dapat meningkatkan motivasi belajar adalah pergaulan teman sebaya (peer-group), seperti halnya yang terdapat dalam penelitian yang dilakukan oleh Maryam bahwa: "perilaku pada masa remaja ditentukan oleh figur otoritas, yaitu kehidupannya lebih banyak dipengaruhi oleh teman sebaya atau peer group". Siswa akan mendapatkan dukungan penuh serta dia akan termotivasi untuk belajar apabila bergaul dengan teman sebaya yang berperilaku baik dan memiliki kemauan yang kuat untuk belajar, namun sebaliknya apabila bergaul dengan teman yang berperilaku kasl atau malas belajar maka konsekuensi yang didapatkan individu adalah penurunan belajar atau memiliki motivasi belajar yang rendah.

Dukungan atau peran teman sebaya dijelaskan (Muhammad Fuad Abdul Baqi: 2013) bahwa Nabi Muhammad saw bersabda yang berbunyi:

"Permisalan teman sebaya yang baik dan yang teman yang buruk ibarat penjual minyak wangi dan seorang pandai besi. Penjual minyak wangi kemungkinan besar akan memberimu minyak wangi, atau engkau bisa membeli minyak wangi darinya. Sedangkan pandai besi, bisa saja (percikan apinya mengenai pakaianmu), dan kalaupun tidak tetap engkau mendapatkan bau asapnya yang tidak sedap". (HR. Bukhari 5534 dan Muslim 2628).

\section{PEMBAHASAN}

\section{Pengertian Teman Sebaya}

Teman sebaya merupakan suatu kelompok pergaulan individu yang memiliki konformitas dari segi usia, hobi atau kebiasaan lainnya. (Damsar: 2009, 74). Adapun pendapat Ivor Morrish yang dikutip Abu Ahmadi (2004:191) beliau menjelaskan makna dari peer group sebagai " a peer is an equel, and a peer group is a group compsoed of individuals who are equales". Jadi teman sebaya adalah kelompok yang terdiri atas sejumlah individu yang cenderung memiliki kesamaan atau kemiripan. Menurut Horrocks dan Benimoff yang dikutip oleh Elizabeth B. Hurloks (alih bahasa Med Meitasari: 2001, 214) teman sebaya merupakan "dunia nyata kawula muda, yang menyiapkan panggung dimana ia dapat menguji diri sendiri dan orang lain". Jadi teman sebaya dapat diartikan sebagai kelompok yang sedang mencari identitas diri. Sedangkan penjelasan dari (Slamet Santosa: 1999, 82) bahwa peer group merupakan suatu kelompok individu yang bisa sukses dalam menjalin hubungan sosial dengan kelompok usianya.

Teman sebaya menurut (Hadi: 2005, 67) adalah suatu kelompok pergaulan memungkinkan terjadinya pendidikan, teman sebaya merupakan sarana mawas diri. Dari kelompok teman 


\section{Al-Hikmah: Jurnal Dakwah, Volume 12, Nomor 2, Tahun 2018 \\ [P. 159-180]}

sebaya juga akan muncul suatu cita-cita yang dapat memberikan makna tersendiri atas kelompok yang dijalin bersama-sama. Adapun latar belakang terbentuknya peer group adalah (Santosa: 2001) sebagai berikut: (1) Adanya perkembangan proses sosialisasi. (2) Setiap individu pada masa remaja membutuhkan penerimaan dan penghargaan diri dari orang lain disekelilingnya. (3) Pada perkembangan remaja orangttua sangat dianjurkan untuk memberikan attention untuk memantau setiap perkembangan yang muncul dalam diri anak, agar anak merasa kehadirannya berarti dan nyaman berada dalam rumah, sehingga remaja memiliki kepribadian yang baik dan positif tanpa merasa diabaikan oleh orang tuanya yang kemudian dirinya tidak menjadi sumber masalah bagi dirinya sendiri maupun orang lain. (4) Masa remaja juga cenderung mengidolakan seseorang atau figur yang ia kagumi sehingga ia akan meniru tingkah laku figur otoritasnya yang dari demikiandia (remaja) dapat menemukan jati dirinya dan dunianya.

Dapat ditarik kesimpulan bahwa teman sebaya atau peer group merupakan suatu kelompok yang menjalin hubungan sosial atas ikatan yang sama, yaitu baik kesamaan dari bentuk usia, hobi, status sosial atau posisi sosial serta kebutuhan dan minat cenderung memiliki kesamaan, beranjak dari konformitas inilah munculnya suatu persahabatan atau pertemanan. Lingkungan teman sebaya yang memberikan dorongan belajar dan memberikan dampak positif bagi siswa akan berdampak pada peningkatan prestasi belajarnya, tetapi siswa yang bergaul pada lingkungan teman sebaya yang negatif dapat menurunkan prestasi belajar siswa seperti rasa senang untuk berkumpul dengan teman sebaya membuat siswa lupa atua tidak memiliki waktu untuk belajar.

Menurut Theodorson yang dikutip Abu Ahmadi (2004:192) ada sejumlah unsur pokok yang harus dilihat dan diketahui dalam mendefenisikan teman sebaya sebagai berikut:

a) Teman atau kelompok sebaya merupakan kelompok primer yang diantara sesama mereka memiliki hubungan yang intim.

b) Teman sebaya terdiri dari individuindividu yang memiliki usia yang sama, dan status sosial yang sama.

c) Teman sebaya dipakai dalam berbagai kalangan baik kalangan anak-anak, remaja dan dewasa bahkan lansia. Namun, fokus pembahasan adalah teman sebaya pada usia remaja yang mengenyam pendidikan di tingkat SLTP.

Untuk lebih memantapkan pemahaman tentang makna dari teman sebaya, penulis mencantumkan beberapa 
ciri-ciri teman sebaya yang dinukil dari

(Slamet Sentosa: 1999 ) sebagai berikut:

a) Organisasi yang dimiliki tidak jelas karena muncul secara otomatis atau spontan, serta semua individu yang ada dalam organisasi tersebut disamaratakan artinya masing-masing individu memiliki kedudukan yang sama. Namun tetap diangkat salah satu siswa untuk memimpin atau mengetuai kelompok (teman yang dianggap paling mendominasi atau paling disegani serta yang paling familiar diantara teman yang lain).

b) Kelompok teman sebaya yang sifatnya sementara, maksudnya kelompok tersebut tidak akan bertahan lama dikarenakan struktur organisasi yang dimiliki tidak jelas apalagi dalam hal keinginan diantara masing-masing yang tidak selamanya sama atau tidak mendapatkan kesepakatan dalam memutuskan sesuatu, karena peer group bukanlah kelompok yang legal, maka kemungkinan besar terjadinya kontradiktif pemahaman diantara mereka sehingga bubarnya kelompok tersebut.

c) Peer group mengajarkan individu tentang kebudayaan luas, artinya dikarenakan setiap kelompok berasal dari masing-masing budaya yang berbeda, maka mereka saling memperkenalkan budayanya yang paling menonjol, paling lazim serta yang paling unik dilakukan oleh masing-masing individu. Sehinggga dipilihlah budaya yang paling sesuai dengan kelompok mereka dan dijadikan sebagai otoritas dari kelompok atau grup teman sebaya tersebut.

Adapun fungsi teman sebaya atau peer group menurut (Abu Ahmadi: 2009) adalah: a) Masing-masing individu dapat bergaul lebih akrab dengan sesama teman yang datang dari budaya yang berbeda-beda.

b) Memiliki tanggung jawab atau peran baru terhadap suatu kelompok.

c) Memiliki pengetahuan yang luas tentang kebudayaan yang dipelajari dari masing-masing teman sebaya yang berasal dari budaya yang berbeda-beda.

d) Teman sebaya mengajarkan tentang mobilitas sosial.

e) Belajar patuh kepada aturan sosial yang impersonal rule of the gameserta memiliki kewibawaan yang impersonal juga.

\section{Sedangkan menurut Slamet \\ Santosa (1999:85) fungsi peer group sebagai berikut:}

a) Teman sebaya mengajarkan moral yang baru.

b) Teman sebaya mengajarkan mobilitas sosial.

c) Teman sebaya merupakan informasi baru bagi orang tua, guru dan masyarakat.

d) Teman sebaya membantu peranan sosial baru yang lebih bertanggung jawab.

e) Dalam kelompok teman sebaya, masing-masing individu memiliki ketergantungan diantara satu sama lain.

\section{Pengertian Motivasi Belajar}

Motivasi berasal dari bahasa latin yaitu movere artinya merupakan suatu gerakan atau dorongan untuk bergerak. Motivasi juga bisa diartikan sebagai motif yang dapat menggerakkan individu untuk 


\section{Al-Hikmah: Jurnal Dakwah, Volume 12, Nomor 2, Tahun 2018 \\ [P. 159-180]}

melakukan aktivitas-aktivitas.yang lebih baik untuk mendapatkan suatu asa yang diimpikan. Motivasi menurut Santrock adalah suatu proses yang dapat memberikan semangat, arah dan kegigihan perilaku yag baik atau positif. Artinya adalah bahwa perilaku yang termotivasi untuk melakukan sesuatu akan terarah, bertahan lama dan penuh energi.

Motivasi adalah suatu daya penggerak atau dorongan yang timbul dari dalam diri individu untuk melakukan suatu perubahan atau tadarruj kearah yang lebih mantap dan positif, sehingga dengan adanya gerakan tadarruj tersebut maka individu semakin berusaha untuk mencari berbagai alternatif-alternatif untuk meningkatkan cara belajarnya, seperti lebih efisien menggunakan waktu, jika belajarnya masih kurang bagus maka ia akan termotivasi untuk belajar diluar jam pelajaran misalnya dengan les tambahan atau les private diluar jam sekolah. (Uno: 2008, 23). Adapun pengertian motivasi menurut (Syah: 2009, 153) adalah suatu dorongan yang muncul baik dari dalam diri inidvidu (motivasi instrinsik) maupun diluar diri individu yang disebut sebagai motivasi ekstrinsik.

Menurut McDonald yang dikutip Oemar Hamalik (2002:173), Motivation is a energy change within the person characterized by affectife arousal and anticipatory goal reaction. Motivasi adalah suatu perubahan energi di dalam peribadi seseorang yang ditandai dengan timbulnya afektif dan reaksi untuk mencapai tujuan. Menurut Sardiman A.M (2007:75), motivasi merupakan serangkaian usaha untuk menyediakan kondisi-kondisi tertentu, sehingga individu ikut serta dan bertanggung jawab dalam melakukan sesuatu. Dan bila ia tidak suka maka akan berusaha untuk meniadakan atau menghilangkan perasaan tidak suka itu.

Sedangkan menurut Atkinson yang yang dikutip RBS Fudyartanta mendefinisikan motivasi sebagai berikut : "The term motivation refers to the arousal of tedency to act to produce one or more effeccts". Motivasi menunjukkan tendensi berbuat yang meningkat. Jadi motivasi merupakan perubahan atau penggerak bagi individu untuk mewujudkan atau mencapai sesuatu yang ia harapkan sesuai dengan keinginan yang ia dambakan. Dengan adanya motivasi yang tinggi, seseorang akan berusaha semampunya agar harapan atau tujuan yang diinginkan akan tercapai dengan optimal dan meningkat dari periode sebelumnya.

Motivasi dan belajar adalah merupakan dua hal yang saling berhubungan atau berakaitan.Belajar merupakan perubahan perilaku atau 


\section{Nur Cahaya Nasution \\ Dukungan Teman Sebaya Dalam Meningkatkan Motivasi Belajar}

tingkah laku yang relatif permanen dan secara potensial perubahan tingkahlaku itu terjadi sebagai hasil praktik atau penguatan yang dilandasi untuk mencapai tujuan tertentu. Menurut Slameto belajar merupakan perubahan tingkah laku individu yang didapatkan dari berbagai pengalaman yang ia alami atau lalui dalam interaksi sosialnya dengan lingkungan sosial. Jadi, belajar merupakan proses perubahan tingkah laku baru berdasarkan pengalaman tau latihan yang diperoleh dari lingkungan sosial.

Dalam setiap pembelajaran muncul yang namanya motivasi belajar. Winkel menjelaskan makna dari motivasi belajar adalah sebagai motivasi yang diterapkan dalam kegiatan pembelajaran yang dapat menggerakkan keseluruhan dari daya penggerak psikis dalam diri siswa untuk bersungguh-sungguh dalam melaksanakan atau mengikuti kegiatan belajar, menjamin keberlangsungan dalam belajar secara efektif kemudian mendapatkan dan memperoleh hasil yang sesuai dengan apa yang diinginkan.

Menurut RBS Fudyartanta (2002:258) motivasi belajar adalah suatu dorongan yang memberikan semangat kepada individu dalam melakukan aktivitas belajar agar mencapai suatu hasil belajar yang sangat memuaskan atau setidaknya memperoleh perubahan yang intens dari masa sebelumnya.Sardiman
A.M (2007:75) menyatakan bahwa yang dimaksud dengan motivasi belajar adalah keseluruhan daya penggerak di dalam diri siswa yang menimbulkan kegiatan belajar, yang menjamin kelangsungan dari kegiatan belajar dan memberikan arah pada kegiatan belajar, sehingga tujuan yang yang dikehendaki oleh subyek belajar itu dapat tercapai.Motivasi belajar adalah merupakan faktor psikis yang bersifat non intelektual.Peranannya yang khas adalah dalam hal penumbuhan gairah, merasa senang dan semangat untuk belajar. Siswa yang memiliki motivasi kuat, akan mempunyai banyak energi untuk melakukan kegiatan atau aktivitas belajar.

Dari pendapat diatas dapat ditarik kesimpulan bahwa motivasi belajar adalah keseluruhan daya penggerak yang berasal dari internal maupun ekstenal individu yang mendorong individu untuk menyiapkan berbagai rangkaian usaha untuk melakukan kegiatan belajar, sehingga jika siswa memiliki motivasi yang begitu kuat dan tinggi dalam belajar, maka siswa tersebut cenderung mendapatkan atau memperoleh hasil yang memuaskan pula.

Adapun macam-macam motivasi belajar itu adalah sebagai berikut:

a. Motivasi instrinsik

Merupakan suatu daya penggerak atau dorongan yang muncul 


\section{Al-Hikmah: Jurnal Dakwah, Volume 12, Nomor 2, Tahun 2018 \\ [P. 159-180]}

dari dalam diri individu, artinya ia mau belajar atas kemauan dirinya sendiri dan adanya suatu tujuan yang ingin dicapai, misalnya individu menginginkan untuk mendapatkan peringkat kelas pertama sehingga ia termotivasi untuk meningkatkan cara belajarnya, dan dapat menggunakan waktu belajar semaksimal mungkin. Kemudian jika dilihat dari dari segi kegiatan belajar yang ia lakukan, maka motivasi instrinsik adalah ingin mendapatkan tujuan yang terkandung dalam tujuan perilaku atau perbuatan itu sendiri. Misalnya seseorang siswa termotivasi untuk belajar dikarenakan ia memang ingin memiliki kapasitas maupun keterampilan atau niat untuk memiliki intelegensi yang kuat murni muncul dari dalam hatinya bukan karena dorongan yang lain.

Dorongan untuk belajar merupakan sumber pada kebutuhan seseorang yang menimbulkan suatu keharusan untuk memiliki kesadaran melakukan aktivitas belajar, sehingga lahirlah individu atau siswa yang terdidik lagi berpengetahuan. Oleh karena itu, siswayang memiliki motivasi instrinsik maka ia akan senantiasa terdorong untuk selalu maju untuk mengikuti dan mengerjakan aktivitas belajar demi tercapainya suatu tujuan yang ia inginkan. Keinginan itu merupakan suatu dorongan yang positif yang timbul dari dalam diri individu, sehingga ia memiliki kesadaran yang begitu kuat betapa ilmu pengetahuan itu sangat penting untuk dipelajari yang suatu saat pasti berguna untuk masa depannya sekaligus menjadi benteng pertahanan diri dalam melakukan sesuatu, artinya adalah dengan bekal ilmu pengetahuan yang dimiliki, maka akan menuntun atau mengarahkan seseorang dalam melakukan suatu perbuatan. Dalam proses belajar, motivasi instrinsik ini sangat berpengaruh efektif dalam menunjang keberhasilan belajar dikarenakan motivasi ini murni datangya dari dalam diri individu, tentunya akan bertahan lama atau permanen tanpa ada pengaruh atau paksaan dari luar dirinya.

b. Motivasi ekstrinsik

Motivasi ekstrinsik ini adalah suatu motif yang aktif karena adanya ransangan dari luar diri individu. Motivasi belajar muncul bukan hanya berasal dari dalam diri individu, melainkan juga motivasi itu berasal dari luar diri individu atau siswa seperti halnya motivasi orang tua, guru, teman sebaya dan lain sebagainya. Model- 
model motivasi ekternal menurut Winkel sebagai berikut:

1) Belajar demi terlaksanakannya suatu kewajiban.

2) Belajar demi menghindari hukuman.

3) Belajar untuk meningkatkan gengsi.

4) Belajar untuk mendapatkan penghargaan dan pujian dari orang lain.

5) Belajar karena merupakan tuntutan tanggung jawab yakni untuk kenaikan pangkat atau jabatan.

Perlu diketahui, pada dasarnya motivasi ekstrinsik ini bukan suatu motivasi yang tidak dibutuhkan dalam pembelajaran atau pendidikan. Setiap motivasi tetap penting dalam menunjang suatu perubahan kearah yang lebih konstruktif tetutama dalam pencapaian prestasi yang lebih baik dalam belajar, karena kemungkinan keadaan siswa yang dinamis dalam mengikuti proses pembelajaran dan adanya komponen-komponen yang begitu kurang menarik sehingga motivasi ekstrinsik ini tetap dibutuhkan dalam pendidikan. Dilain hal motivasi ekstrinsik ini sebagai pelengkap atau pendukung bagi individu yang kurang memiliki motivasi dalam dirinya untuk belajar. Dengan adanya dorongan dari luar, kemungkinan besar individu akan lebih maju dan giat untuk belajar. Misalnya siswa membayangkan atau mengkaji sejarah para tokoh-tokoh yang terkenal seperti halnya Thomas
Alfa Edision, karena bukan kegigihan beliau dalam melakukan eksperimen kemungkinan besar manusia tidak akan bisa menggunakan sumber listrik, hanya saja ia tetap sabar dan gigih meskipun selalu gagal, namun dia tetap mengulang atau terus berlatih dan mencoba sehingga eksperimen yang ke 9999 ia berhasil menciptakan sebuah lampu pijar yang dinikmati manusia samapai sekarang.

$$
\text { Adapun }
$$

faktor-faktor

munculnya motivasi sebagaimana halnya yang dikemukakan oleh Dimyati dan Mudjiono adalah sebagai berikut:

1) Cita-cita atau aspirasi jiwa

Dari otonomi yang muncul dalam diri siswa, akan adanya kepuasan tersendiri berkat hasil maupun prestasi belajar yang dicapai, karena motivasi yang begitu tinggi sehingga pelaksanaan dalam kegiatan belajar semakin tinggi pula sehingga munculnya kemandirian dan tanggung jawab siswa untuk meraih apa yang ia inginkan. Dalam proses pembelajaran, reward and funishment sangat berkaitan erat untuk menunjang keberhasilan individu dalam belajar. Reinforcement serta kemauan akan memunculkan cita-cita dalam belajar. Untuk mewujudkan sebuah 


\section{Al-Hikmah: Jurnal Dakwah, Volume 12, Nomor 2, Tahun 2018 \\ [P. 159-180]}

cita-cita membutuhkan proses atau waktu yang sangat lama untuk mendapatkannya. Dengan cita-cita yang dimiliki individu tersebut maka dapat meningkatkan dan memperkuat motivasinya dalam belajar.

2) Kemampuan siswa

Keinginan siswa perlu diimbangi dengan kemampuan sehingga bisa memperkuat motivasi siswa untuk mengerjakan tugastugas belajarnya.

3) Kondisi siswa

Kondisi siswa baik dari segi fisik maupun rohani sangat berpengaruh dalam mengikuti proses belajar. Siswa yang memiliki kondisi fisik yang sehat, maka perhatian belajar dan motivasi belajarnya akan meningkat dan penuh antusias, begitu juga sebaliknya.

4) Kondisi lingkungan siswa

Kondisi lingkungan yang kondusif akan meningkatkan motivasi dan keefektifan siswa dalam belajar.

5) Unsur-unsur dinamis dalam belajar dan pembelajaran

Perasaan, kemauan, perhatian dan pikiran siswa mengalami perubahan dikarenakan pengaruh dari pengalaman hidup yang ia dapatkan. Kemudian pengalaman yang paling berpengaruh dalam motivasi dan perilaku belajar didapatkan dari pengaruh teman sebaya.

6) Upaya guru dalam menjelaskan atau memberikan materi pelajaran kepada siswa

Dalam proses belajarmengajar, dalam lingkungan sekolah guru memiliki kedudukan figur otoritas yang utama yang diteladani oleh siswa. Kualitas guru sangat tergantung pada kemampuan atau kecakapan guru dalam mengajar. Untuk itu, motivasi siswa juga bisa meningkat karena pengaruh atau nasehat dari guru.

Untuk lebih memantapkan pemahaman terkait tentang motivasi belajar ini, maka penulis mencantumkan beberapa peran motivasi dalam belajar menurut Iskandar sebagai berikut:

a) Motivasi sebagai penggerak atau pendorong kegiatan belajar

Motivasi berperan sebagai motor penggerak bagi setiap siswa baik motivasi itu berasal dari dalam dirinya maupun diluar 
dirinya untuk aktif dalam melakukan kegiatan pembelajaran.

b) Motivasi dapat memperjelas tujuan dari pembelajaran

Motivasi bertalian erat dengan tujuan yang hendak dicapai, tanpa motivasi, maka tidak akanada tujuan yang hendak dicapai oleh siswa, begitu juga sebaliknya tanpa adanya motivasi maka tujuan itu akan sulit untuk dicapai atau didapatkan. Dengan motivasi ini, maka seorang siswa akan aktif untuk mengerjakan berbagai tugas sekolah demi tercapainya suatu target yang optimal.

c) Motivasi dapat menyeleksi arah perbuatan

Motivasi ibarat kompas yang menunjukkan arah dan caracara atau strategi siswa dalam belajar demi mendapatkan atau memperoleh prestasi yang lebih baik. Dengan adanya motivasi ini, maka siswa akan tahu dan siap serta tangkas untuk mengikuti kegiatan belajar dilingkungan sekolah.

d) Peran motivasi internal dan eksternal dalam pembelajaran

Dalam kegiatan pembelajaran, motivasi internal ini muncul dari dalam diri siswa sedangkan motivasi eksternal muncul dari luar diri siswa seperti pengaruh dari guru, orang tua dan teman sebaya.Jadi, untuk mendapatkan hasil yang lebih baik, maka sudah seharusnya dan sebaiknya siswa mensinergikan kedua motivasi ini dalam rangka mengikuti kegiatankegiatan belajar yang ada disekolah.

e) Motivasi menentukan ketekunan dalam pembelajaran

Seorang siswa yang memiliki motivasi tinggi, tentu dia akan berusaha belajar tekun dan seoptimal mungkin. Dengan harapan untuk mendapatkan hasil yang lebih baik dari sebelumnya.

f) Motivasi dapat melahirkan prestasi Tinggi atau rendahnya prestasi yang dimiliki atau didapatkan siswa tergantung motivasi yang ia miliki dalam belajar. Sehingga motivasi memiliki peranan yang begitu penting dalam meraih sebuah prestasi belajar.

\section{Dukungan Teman Sebaya dalam}

\section{Meningkatkan Motivasi Belajar}

Menurut penelitian para ahli selain peran keluarga siswa dalam hal ini orang tua dan guru sebagai lingkungan utama yang berpengaruh terhadap prestasi 


\section{Al-Hikmah: Jurnal Dakwah, Volume 12, Nomor 2, Tahun 2018 \\ [P. 159-180]}

belajar siswa, peran teman sebaya juga mempunyai pengaruh yang cukup besar dalam meningkatkan motivasi belajar siswa itu sendiri. Teman sebaya ibarat lingkungan sosial pertama, dimana remaja belajar untuk hidup bersama dan saling menghargai orang lain yang bukan dari lingkungan keluarganya.

Karena anak butuh pengakuan, dia akan berusaha mengikuti standar yang berlaku di kelompok sebayanya. Anak biasanya akan mengalami tekanantekanan dalam pergaulannya, agar mengikuti hal-hal yang biasa dilakukan dalam kelompoknya, sesuai standar mereka. Tekanan tersebut dapat berupa tekanan positif dan tekanan negatif. Mempunyai teman yang mendorong untuk berusaha lebih keras di sekolah dapat memberikan semangat atau motivasi jika anak belum melakukan yang terbaik.Teman juga mampu mencegah melalaikan kewajiban dan menolong di saat kesulitan.Mereka dapat saling memotivasi dan mengarahkan ke arah yang benar atau positif. Banyak anak yang mampu lepas dari kebiasaan merusak diri sendiri karena pengaruh teman sebaya yang penuh perhatian (Herron dan Peter: 2005, 143). Hal-hal tersebut merupakan contoh tekanan sebaya positif.

Tekanan sebaya positif dapat membawa perilaku siswa menjadi positif pula, termasuk juga dalam meningkatkan motivasi belajar. Jika teman sebaya mempunyai kebiasaan belajar yang baik, saling mengingatkan jika salah satunya merasa malas, membantu mengajari teman yang mendapat nilai buruk, tentu motivasi belajar yang baik atau semakin meningkat maka hasil belajar akan diraih dengan mudah pula. Sebaliknya, tekanan sebaya yang negatif akan mendorong perilaku destruktif. Misalnya, apabila anak suka bergaul dengan mereka yang tidak sekolah, maka ia akan malas belajar, sebab cara hidup anak bersekolah berlainan dengan anak yang tidak bersekolah (Abu Ahmadi dan Widodo Supriyono, 1991: 87).

Selain itu, kegiatan-kegiatan yang dijalani saat bergaul juga mampu menentukan motivasi belajar.Kegiatan yang dilakoni lebih banyak membawa manfaat, menjadi sarana untuk mawas diri, dan mampu menimbulkan citacita.Intensitas pertemuan juga terjadi cukup sering, sehingga tumbuhlah keakraban antar anggota kelompok teman sebaya, karena itu teman sebaya sangat berperan untuk meningkatkan motivasi belajar pada siswa.

Remaja di dalam kelompok sebayanya membina hubungan pertemanan atau persahabatan, merumuskan dan memperbaiki konsep 
dirinya untuk dinilai oleh orang lain yang sejajar dengan dirinya. Mereka memiliki rasa ingin tahu yang tinggi sehingga seringkali ingin mencoba-coba, mengkhayal, merasa gelisah, serta berani melakukan pertentangan jika dirinya merasa disepelekan atau tidak dianggap.Sebagaimana dijelaskan oleh Singgih DS bahwa "Kebanyakan remaja menemukan problem solving setelah mereka berkumpul dengan rekan sebaya untuk melakukan kegiatan bersama.Mereka melakukan suatu kegiatan secara berkelompok sehingga berbagai kendala dapat diatasi”.

Memilih teman sebaya akan memberi pengaruh yang berarti bagi kehidupan remaja ke depannya baik pengaruh positif maupun pengaruh negatif. Hal ini dikarenakan dalam masa remaja inilah hubungan pertemanan terjalin baik di lingkungan sekolah maupun di lingkungan tempat tinggal, yang meliputi tingkah laku, kegemaran, perilaku keagamaan, dan motivasi belajar. Interaksi teman sebaya di dalam suatu hubungan pertemanan yang kurang baik dapat berpengaruh terhadap berbagai aspek kehidupan dan prestasi belajar kelompok sebaya (peer group) yang memberikan pengaruh positif, maka siswa akan memiliki motivasi belajar yang tinggi karena siswa tidak mau kalah berprestasi dengan anggota kelompok lainnya.

Sedangkan teman sebaya (peer group) yang memberikan pengaruh yang negatif maka siswa kurang memiliki motivasi belajar, karena mereka lebih cenderung untuk melakukan hal-hal yang bersifat bersenang-senang. Kelompok atau teman sebaya yang membawa pengaruh positif akan mampu meningkatkan motivasi belajar yang tinggi terhadap pendidikan siswa, timbulnya rasa solidaritas, mampu bekerja sama dengan orang lain dan lain sebagainya. Sedangkan pergaulan kelompok teman sebaya yang membawa pengaruh negatif akan membuat siswa mengabaikan pendidikannya, cenderung mengarahkan untuk berperilaku menyimpang, timbulnya kenakalan remaja dan perilaku destruktif lainnya.

Hakekat motivasi belajar itu adalah dorongan yang berasal dari internal maupun eksternal pada diri seseorang untuk dapat melakukan perubahan yang lebih baik.Salah satu faktor yang mempengaruhi motivasi belajar adalah pergaulan kelompok teman sebaya (peer group). Kuatnya pengaruh kelompok sebaya (peer group) dikarenakan remaja lebih banyak berada diluar rumah bersama dengan teman-teman sebaya untuk membentuk suatu komunitas, maka dapatlah dimengerti bahwa pengaruh 
teman-teman sebaya pada sikap, pembicaraan, minat, motivasi, penampilan, dan perilaku lebih besar dari pada pengaruh keluarga (Hurlock, 2002).

Bantuan belajar oleh teman sebaya dapat menghilangkan kecanggungan, bahasa teman sebaya lebih mudah dipahami, selain itu dengan teman sebaya tidak ada rasa enggan, rendah hati dan malu untuk bertanya maupun minta bantuan.Fungsi kelompok teman sebaya untuk menciptakan pembelajaran yang terkait dengan aktifitas belajar. Memperluas pandangan serta wawasan agar dapat diterima oleh lingkungan dimana mereka berada.

Adapun cara yang dilakukan untuk mengukur pengaruh teman sebaya dalam meningkatkan motivasi belajar siswa adalah sebagai berikut:

a. Interaksi sosial

$$
\text { Terjadinya pembentukan }
$$

kelompok teman sebaya diawali dengan adanya interaksi sosial, dimana interaksi sosial merupakan sebuah kunci yang paling penting dalam menjalin relasi sosial dengan lingkungan sosial maupun orang lain. oleh karena itu interaksi sosial ini tidak bisa dipisahkan dalam kehidupan bermasyarakat. Interaksi sosial menurut (Soerjono Soekanto: 1988, 92) merupakan hubungan sosial yang dinamis yang menyangkut hubungan antara orang perorangan, antar kelompok dengan kelompok manusia.

Syarat terjadinya interaksi sosial adalah melalui hubungan kontak sosial.Kontak sosial adalah hubungan yang terjadi diantara masing-masing individu secara langsung dan kontinu atau prosesnya melalui face to face. Kontak sosial ini terbagi dua yaitu: kontak sosial primer dan kontak sosial sekunder. Kontak sosial primer misalnya: tatkala bertemu individu saling sapa menyapa dan saling berjabat tangan. Sedangkan kontak sosial sekunder memiliki mediasi misalnya individu termotivasi belajar dikarenakan temannya si Ani misalnya memiliki prestasi yang tinggi dan selalu di elu-elu kan oleh guru maupun teman-teman yang lain.

$\begin{array}{lll}\text { Gillin } & \text { dan } & \text { Gillin } \\ \text { mengklasifikasikan } & \text { interaksi } & \text { sosial } \\ \text { menjadi dua bagian, yaitu: } & \end{array}$

a) Proses asosiatif

(1) Kerja sama, merupakan suatu aktivitas yang dilakukan oleh kelompok individu atau teman sebaya untuk mencapai tujuan bersama.

(2) Akomodasi, merupakan suatu usaha yang dilakukan manusia untuk menghilangkan atau mengurangi maupun meredakan 
suatu pertikaian atau perselisihan yang terjadi antara individu dengan kelompok untuk mencapai kestabilan.

(3) Asimilasi, merupakan suatu pandangan yang berbeda pada awalnya dengan kelompok lain.

(4) Akulturasi, dari perbedaan pandangan atu budaya tersebut, lambat laun diterima juga, kemudian diproduksi menjadi kebudayaan tersendiri tanpa menghilangkan kepribadian kebudayaan tersebut.

b) Proses disosiatif

(1) Persaingan kompetisi adalah bentuk perjuangan secara damai yang terjadi apabila dua pihak berlomba atau berebut untuk mencapai suatu tujuan atau barang yang sama di mana persediaannya terbatas. Misalnya persaingan untuk mendapat rangking yang baik (1).

(2) Contravention, adanya ketidakpuasan tersendiri atas rencana maupun tindakan yang akan dilakukan dan dibentuk untuk mencapai suatu tujuan yang telah disepakati dan diharapkan bersama.
(3) Pertentangan atau pertikaian, adalah suatu proses sosial di mana individu atau kelompok manusia berusaha untuk memenuhi dan mendapatkan apa yang ia inginkan dengan jalan menentang pihak lain dengan ancaman dan kekerasan.

c) Komunikasi.

Bentuk yang paling penting dari komunikasi adalah individu dapat menafsirkan apa yang sedang dibahasakan oleh orang lain, baik dari segi verbal maupun non verbal. Dengan adanya komunikasi, maka individu mengetahui perasaanperasaan yang terjadi pada setiap individu dengan mengamati gestur (bahasa tubuh) nya.

Kelompok teman sebaya merupakan lingkungan sosial atau kondisi di sekitar lingkungan siswa yang menjadi salah satu faktor yang dapat meningkatkan motivasi belajar seseorang. Lingkungan sosial seperti para guru, para tenaga pendidik (kepala sekolah dan wakilwakilnya) dan teman-teman sekelas dapat mempengaruhi semangat belajar seorang 


\section{Al-Hikmah: Jurnal Dakwah, Volume 12, Nomor 2, Tahun 2018 \\ [P. 159-180]}

siswa.Teman sebaya termasuk ke dalam lingkungan sosial yang dapat meningkatkan motivasi belajar.Lingkungan sosial seperti lingkungan sosial sekolah yang di dalamnya termasuk guru, administrasi dan teman sebaya.

Interaksi atau relasi yang baik antara siswa yang satu dengan yang lainnya yang terjalin di dalam kelompok teman sebaya juga akan memberikan dukungan dalam meningkatkan motivasi belajar siswa, karena dengan adanya relasi yang baik akan terciptanya suasana belajar yang lebih baik pula sehingga akan memberi dampak terhadap prestasi belajar siswa. Menciptakan relasi yang baik antar siswa adalah perlu, agar dapat memberikan pengaruh positif terhadap belajar siswa (Slameto, 2003).

\section{KESIMPULAN}

Fungsi kelompok teman sebaya, yaitu interaksi dengan teman sebaya untuk meningkatkan kemajuan atau motivasi belajar untuk berprestasi tinggi, peranan teman sebaya dalam menumbuhkan kedisiplinan belajar akan mampu memecahkan masalah, tindakan anggota- anggotanya untuk saling membangkitkan motivasi belajar, perubahan tingkah laku sebagai hasil belajar untuk mendorong kemajuan yang bersifat inovatif dan produktif sehingga tujuan belajar dapat dicapai seoptimal mungkin. Fungsi kelompok teman sebaya di lihat dari proses belajar mengajar memegang peranan penting dalam kehidupan remaja, dengan adanya kelompok teman sebaya, anggota yang ada di dalam kelompok tersebut bisa membentuk kelompok belajar, sehingga dapat saling bertukar pikiran memecahkan masalah, seperti tugas di sekolah atau berdiskusi mengenai kesulitan belajar, belajar bersama untuk menghadapi ujian sekolah atau saling memotivasi antar anggota dalam hal belajar.

\section{DAFTAR PUSTAKA}

Ahmadi, Abu \& Supriyono, Widodo. (1991). Psikologi Belajar. Jakarta: Rineka Cipta.

Alfian, I. N. \& Suminar (2003).Perbedaan tingkat kebermakanaan hidup remaja akhir pada berbagai status identitas ego dengan jenis kelamin sebagai kovariabel. Dalam Jurnal Perkembangan : Insan media, 5, 2,87-109.

Baihaqie, A.N. (2011). Peranan peer group terhadap aktivitas belajar siswa kelas 5 dalam pelajaran PKN di SDN 5 Praya. Artikel Pendidikan, hlm.37-43.

Cairns, R.B, \& Neckerman. (1988). Social network and aggressive behavior : 
peer support or peer rejection?. DevelopmentalPsychology

Journal, 24, 6, 815-823.
Winkel, W.S. (1983). Psikologi Pendidikan dan Evaluasi Belajar. Jakarta: PT. Gramedia.

Hartinah, S. (2009). Konsep dasar bimbingan kelompok. Bandung: PT Refika Aditama.

Lailatur Rohmah. 2012. Pengaruh Dukungan Teman Sebaya dan MinaT Belajar Terhadap Prestasi Belajar Ilmu Nahwu Pada Santri Madrasah Salafiyah III Pondok Pesantren Al-Munawwir Komplek "Q" Krapyak Yogyakarta. Yogyakarta: Skripsi Prodi Psikologi, Fakultas Ilmu Sosial dan Humaniora, UINSunan Kalijaga.

Ryan, A. M. yang berjudul. 2001. The peer group as a context for the development of young adolescent motivation and achievement. Child Development. Volume 72, Number 4, Pages 1135-1150.

Slameto.(2003). Belajar dan faktor-faktor yang mempengaruhinya. Jakarta: Bumi Aksara.

Syah, M. (2004).Psikologi pendidikan dengan pendekatan baru. Bandung: PT. Remaja Rosda Karya.

Santosa, S. (2009).Dinamika kelompok. Jakarta: Bumi Aksara.

Slameto.(2010). Belajar dan FaktorFaktor yang Mempengaruhinya.Jakarta: Rineka Cipta.

Sarlito W. Sarwono. 2006. Psikologi Remaja. Jakarta: PT RajaGrafi ndo Persada.

Santrock, John W,. 2007. Psikologi Pendidikan. Jakarta: Kencana

Adolescence (perkembangan remaja) terj. Jakarta: Erlangga 